\title{
KONVERSI LAHAN SAWAH DI SUBAK PETANGAN KECAMATAN DENPASAR UTARA
}

\author{
Rice Field Conversion in Subak Petangan, North Denpasar District
}

\author{
I Gusti Jaya Wiraraja, I Made Antara, Ni Wayan Sri Astiti
}

Program Studi Magister Agribisnis, Fakultas Pertanian, Universitas Udayana, Bali, Indonesia

Email:jaya_raja@rocketmail.com

\begin{abstract}
Agricultural land has an important role as a medium to increase the income, standard of living, and welfare of farmers within. This study aims to 1) analyze the factors that influence the motivation of farmers in converting paddy fields, 2) analyze the social and economic impacts of land conversion in Subak Petangan, North Denpasar District. This research was carried out in the Subak Petangan Denpasar Utara which was chosen using census with a population of 40 farm owner. The main instruments used in the data collection is questionnaires. Data analysis techniques used are factor analysis method and quantitative qualitative analysis. The study showed that land conversion are affected by internal and external factors. Internal factors are formed by the number of family member, level of education, life necessities (Maslow's hierarchy of needs), income from agricultural product. External factors are formed by lifestyle indicators, interest of the younger generation for farming, access to land management, availability of water irrigation. The sosial impact of land conversion are hampered on irrigation channels, the emergence of conflicts between farmers and owners of settlements, deterioration of cultural values in Subak Petangan, North Denpasar District and the economy impact are decreases in food source. All parties including the government as well as the subak member should be able to control and develop program or regulation to repress the land conversion's rate. Sosialy and economically, land conversion in Subak Petangan generate bad impact on the environment and culture around Subak Petangan rice field area.
\end{abstract}

Keyword: conversion of paddy fields, internal factors, external factors

\begin{abstract}
ABSTRAK
Lahan pertanian memiliki peranan penting sebagai media peningkatan penghasilan, taraf hidup, dan kesejahteraan petani yang ada didalamnya. Penelitian ini bertujuan untuk 1) menganalisis faktor-faktor yang mempengaruhi motivasi petani dalam mengkonversi lahan sawah, 2) menganalisis dampak sosial dan ekonomi terhadap konversi lahan di Subak Petangan Kecamatan Denpasar Utara. Penelitian ini dilaksanakan di Subak Petangan Kecamatan Denpasar Utara yang dipilih secara sampling jenuh (sensus) dengan populasi berjumlah 40 orang yaitu pemilik penggarap. Instrument yang digunakan dalam pengumpulan data adalah kuisioner, Teknik analisis data menggunakan metode analisis faktor dan analisis deskriptif kualitatif. Hasil penelitian menunjukkan konversi lahan dipengaruhi oleh faktor internal dan eksternal. Faktor internal dibentuk oleh jumlah anggota keluarga, pendidikan, kebutuhan hidup (Konsep Teori Hierarki Kebutuhan Maslow), pendapatan hasil pertanian. Faktor eksternal dibentuk oleh indikator gaya hidup, minat generasi muda untuk bertani, akses pengelolaan lahan, ketersediaan air irigasi. Dampak konversi lahan terhadap sosial yaitu terhambatnya saluran irigasi, timbulnya konflik antara petani dengan pemilik pemukiman, terkikisnya nilai budaya di Subak Petangan Kecamatan Denpasar Utara, dan dampak ekonomi yaitu berkurangnya sumber pangan, petani tidak mempunyai pekerjaan tetap, meningkatnya tingkat penganguran, adanya perubahan pola kehidupan petani. Seluruh pihak terkait baik pemerintah maupun prajuru subak harus mampu untuk mengontrol dan membuat program atau aturan dalam menekan laju konversi lahan. Pada dampak sosial dan ekonomi dalam konversi lahan di Subak Petangan sangat berdampak buruk terhadap lingkungan dan budaya pada lahan sawah Subak Petangan.
\end{abstract}

Kata kunci: konversi lahan sawah, faktor internal, faktor eksternal 


\section{PENDAHULUAN}

\section{Latar Belakang}

Pembangunan nasional yang berkesinambungan bertujuan mewujudkan masyarakat adil, merata,material dan spiritual berdasarkan Pancasila dan UUD 1945. Dengan demikian dalam masyarakat diperlukan penggalian potensi yang ada baik potensi sosial, ekonomi maupun budaya untuk mencapai kesejahteraan masyarakat daerah bersama pada setiap daerah. Secara makro kebudayaan Bali merupakan bagian dari kebudayaan Indonesia, struktur kebudayaan tersebut dimanfaatkan dan diaktualisasikan melalui lembaga-lembaga tradisional. Pertanian secara alamiah sangat dibutuhkan untuk menopang kehidupan dan kelangsungan ekosistem masyarakat Bali. Hal ini sepertinya tidak hanya berlaku pada masa lampau, melainkan juga masa sekarang dan yang akan datang.

Negara Indonesia dikenal sebagai negara agraris, yang kaya akan pertaniannya karena memiliki jumlah penduduk sangat besar. Jumlah penduduk tersebut semakin bertambah setiap tahunnya. Sehingga, di Indonesia rentan akan terjadinya alih fungsi lahan. Dimana lahan produktif dijadikan perumahan untuk menunjang pertambahan penduduk.

Memasuki era globalisasi diperlukan sarana dan prasarana untuk menunjang terlaksananya pembangunan, salah satunya adalah tanah. Tanah memegang peranan yang penting sebagai lahan untuk merealisasikan pembangunan dalam hal ini adalah pembangunan fisik. Seperti diketahui, tanah tidak dapat dipisahkan dengan manusia karena tanah merupakan salah satu faktor penting dalam kehidupan manusia. Tanah merupakan tempat pemukiman, tempat melakukan kegiatan usaha manusia demi meningkatkan taraf hidup mereka, bahkan sesudah matipun masih memerlukan tanah.

Lahan pertanian merupakan lahan yang strategis dan berperan penting dalam perekonomian nasional dan kelangsungan hidup masyarakat, terutama dalam penyedia lapangan kerja dan penyediaan pangan dalam negeri. Kesadaran terhadap peran tersebut menyebabkan sebagian besar masyarakat masih tetap memelihara kegiatan pertanian mereka meskipun negara telah menjadi negara industri. Sumber daya lahan merupakan sumber daya alam yang sangat penting untuk kelangsungan hidup manusia. Salah satu penyebab yang sering kita dapat dalam pemanfaatan lahan adalah adanya alih fungsi (konversi) lahan.

Lahan pertanian memiliki peranan penting sebagai media peningkatan penghasilan, taraf hidup, dan kesejahteraan petani yang ada didalamnya. Kenyataan bahwa hasil pertanian dipandang tidak cukup mampu memenuhi harapan petani, berdampak pada keputusan masyarakat untuk menjual lahannya. Fenomena tersebut menjadi salah satu sebab usaha pertanian dari tahun ke tahun semakin menyusut. Dengan demikian, lahan sawah menjadi semakin menyusut melalui derasnya konversi lahan pertanian menjadi bukan lahan pertanian sebagai dampak kemajuan pembangunan infrastruktur pendukung kepariwisataan Bali.

Subak Petangan terletak di Kecamatan Denpasar Utara mempunyai luas lahan $60 \mathrm{Ha}$ pada tahun 2014. Dari tahun ke tahun wilayah Subak Petangan menyusut seluas 25\% menjadi 45 Ha pada tahun 2017. Faktor pemicu dalam konversi lahan adalah kebutuhan petani yang sangat banyak dan tawaran investor yang membeli lahan sawah dengan harga cukup tinggi, membuat petani menjual lahan sawahnya. Hal ini disebabkan kebutuhan lahan yang sangat dibutuhkan oleh manusia untuk tempat tinggal, tempat melakukan usaha, pemenuhan akses umum dan fasilitas lain sehingga terjadinya alih fungsi lahan yang membuat lahan di Subak Petangan menyusut.

\section{Tujuan Penelitian}

Tujuan penelitian ini adalah (1) Menganalisis faktorfaktor yang mempengaruhi motivasi petani dalam mengkonversi lahan sawah di Subak Petangan Kecamatan Denpasar Utara. (2) Menganalisis dampak konversi lahan terhadap kondisi sosial dan ekonomi petani di Subak Petangan Kecamatan Denpasar Utara.

\section{METODE PENELITIAN}

\section{Waktu dan Lokasi Penelitian}

Penelitian dilaksanakan pada bulan Mei sampai Agustus 2018 dengan bahwa peneliti mewawancarai pemilik sekaligus penggarap yang sudah habis menjual lahan sawahnya serta mendapatkan informasi terkait konversi lahan di Subak Petangan Kecamatan Denpasar Utara.

\section{Jenis dan Sumber Data}

Jenis data yang digunakan terdiri atas data kuantitatif dan kualitatif. Data kuantitatif dalam penelitian ini berupa jumlah lahan sawah petani yang mengkonversi lahannya, indikator-indikator variabel yang ada pada kerangka konsep motivasi dan sebagainya. Data kualitatif pada penelitian ini adalah data keterangan seperti menganalisis faktor-faktor yang mempengaruhi motivasi petani dalam mengkonversi lahan sawah di Subak Petangan, menganalisis dampak sosial dan ekonomi dari Subak Petangan, dan sebagainya.

Data primer didapatkan melalui wawancara dari anggota Subak, Pekaseh yang terkait tentang fenomena konversi lahan yang terjadi melalui wawancara, uji kuesioner, dan sebagainya. Data sekunder seperti; struktur organisasi Subak, jumlah anggota, luas wilayah pertanian di Subak Petangan.

\section{Populasi dan Sampel}

Populasi pada penelitian ini adalah Populasi dalam penelitian ini adalah mewawancarai petani pemilik sekaligus penggarap yang lahannya sudah terjual seluruhnya di Kecamatan Denpasar Utara pada saat ini sebanyak 40 orang. 


\section{Metode Pengumpulan Data}

Data yang digunakan dalam penelitian ini dikumpulkan dengan melalui metode (1) Wawancara terstruktur, (2) Wawancara mendalam, (3) Metode dokumentasi.

\section{Metode Analisis Data}

Analisis data yang digunakan dalam penelitian ini dibagi menjadi dua bagian, yaitu Statistik deskriptif dan Metode Analisis Faktor.

\section{Analisis Statistik Deskripitif}

Pada penelitian ini statistik deskriptif menganalisis tujuan satu dan dua yaitu: faktor-faktor yang mempengaruhi motivasi petani dalam mengkonversi lahan sawah dan dampak sosial dan ekonomi konversi lahan di Subak Petangan Kecamatan Denpasar Utara.

\section{Metode Analisis Faktor}

Analisis faktor adalah kajian tentang saling ketergantungan antara variabel-variabel, dengan tujuan untuk menemukan himpunan variabel-variabel baru, yanglebih sedikit jumlahnya dari pada variabel semula, dan yang menunjukkan yang mana di antara variabelvariabel semula tersebut yang merupakan faktor-faktor persekutuan (Suryanto, 1988). Dalam analisis faktor, variabel-variabel dalam jumlah besar dikelompokkan dalam sejumlah faktor yang mempunyai sifat dan karakteristik yang hampir sama, sehingga lebih mempermudah pengolahan. Pengelompokan dilakukan dengan mengukur korelasi sekumpulan variabel dan selanjutnya menempatkan varibel-variabel yang berkorelasi tinggi dalam satu faktor, dan variabelvariabel lain yang mempunyai korelasi relatif lebih rendah ditempatkan pada faktor yang lain.

Supranto (2004) mengemukakan bahwa langkahlangkah dalam menentukan analisis faktor sebagai berikut.

\section{1) Pemeriksaan Matriks Korelasi}

Seperti dijelaskan sebelumnya bahwa analisis faktor didasari oleh korelasi antara variabel-variabel yang digunakan. Variabel awal yang digunakan merupakan variabel yang saling berkorelasi diharapkan setelah dilakukan analisis faktor akan terbentuk set variabel baru yang lebih sedikit dan tidak berkorelasi. Oleh karena itu, langkah pertama perlu dicek apakah terdapat korelasi antar variabel yang diteliti, karena jika tidak terdapat korelasi maka analisis faktor yang digunakan menjadi tidak berguna.

Pemeriksaan matriks korelasi dapat dilakukan dengan tiga cara yaitu;
a. Uji Bartlett
b. Uji KMO
c. Uji MSA
a. Uji Bartlett (Bartlett Test of Sphericity)

Pengujian ini digunakan untuk melihat apakah matriks korelasi bukan merupakan matriks identitas. Tujuan dari melihat apakah matriks korelasi merupakan matriks identitas atau bukan adalah agar penyusutan dimensi peubah menjadi lebih sederhana dan bermanfaat tanpa banyak kehilangan informasi sebelumnya. Apabila dari uji Bartlett hasilnya signfikan, maka matriks korelasi bukan matriks identitas. Maka penyusutan dimensi peubah tersebut bermakna untuk dilakukan analisis komponen utama. Dengan kata lain, pengurangan peubah akan mempunyai arti dan kegunaan.

Rumus Bartlett sebagai berikut.

$$
\chi 2=(\ln n)\left\{B-\Sigma d k \log s_{i}^{2}\right\}
$$

Keterangan :

$\mathrm{n} \quad=$ jumlah data

$\mathrm{B}=(\Sigma \mathrm{dk}) \log \mathrm{s}^{2} ;$ yang mana $\mathrm{s}^{2}=\frac{\Sigma\left(d k s_{i}^{2}\right)}{\Sigma d k}$

$\mathrm{Si}^{2}=$ varians data untuk setiap kelompok ke-i

$\mathrm{dk}=$ derajat kebebasan

b. Uji KMO (Kaiser Meyer Olkin)

KMO digunakan untuk mengukur kecukupan sampling (sampling adequacy). Nilai ini membandingkan besarnya koefisien korelasi terobservasi dengan koefisien korelasi parsial.

Rumus Uji KMO (Kaiser Meyer Olkin) adalah;

$$
\begin{aligned}
& \mathrm{KMO}=\sum \mathrm{i} \sum \mathrm{i} \neq \mathrm{jr} 2 \mathrm{ij} \quad ; \mathrm{i}=1,2, . . \mathrm{p} ; \mathrm{j}=1,2, \ldots, \mathrm{p} \\
& \sum i \sum i \neq j+2 i j+\sum i \sum i \neq j a 2 i j
\end{aligned}
$$

Keterangan:

rij = koefisien korelasi sederhana antara peubah $\mathrm{i}$ dan $\mathrm{j}$

alphaij = koefisien korelasi parsial antara peubah $\mathrm{i}$ dan $\mathrm{j}$

Menurut Kaiser (1970) dalam Widarjono (2010) penilaian uji KMO seperti yang terlihat pada Tabel 1 .

Tabel 1. Penilaian Uji KMO

\begin{tabular}{ll}
\hline \multicolumn{1}{c}{ Rentang Nilai KMO } & \multicolumn{1}{c}{ Kategori Penilaian } \\
\hline $0,9 \leq \mathrm{KMO} \leq 1,0$ & $\begin{array}{l}\text { data sangat baik (marvelous) } \\
\text { untuk analisis faktor }\end{array}$ \\
\hline $0,8 \leq \mathrm{KMO}<0,9$ & $\begin{array}{l}\text { data baik (meritorious) untuk } \\
\text { analisis faktor }\end{array}$ \\
\hline $0,7 \leq \mathrm{KMO}<0,8$ & $\begin{array}{l}\text { data cukup (middling) untuk } \\
\text { analisis faktor }\end{array}$ \\
\hline $0,6 \leq \mathrm{KMO}<0,7$ & $\begin{array}{l}\text { data kurang (mediocre) } \\
\text { untuk analisis faktor }\end{array}$ \\
\hline $0,5 \leq \mathrm{KMO}<0,6$ & $\begin{array}{l}\text { data buruk (miserable) untuk } \\
\text { analisis faktor }\end{array}$ \\
\hline $\mathrm{KMO} \leq 0,5$ & $\begin{array}{l}\text { data tidak dapat diterima } \\
\text { (unacceptable) untuk analisis } \\
\text { faktor }\end{array}$ \\
\hline
\end{tabular}




\section{c. Pengujian dengan MSA}

Selanjutnya untuk menilai kelayakan setiap variabel untuk dianalisis faktor digunakan kriteria Measure of Sampling Adequacy(MSA). Hair, et al (1998) menyatakan bahwa MSA merupakan ukuran lain yang digunakan untuk mengukur interkorelasi antar variabel dan kesesuaian dari analisis faktor. Hair (1998) juga menyatakan bahwa kenaikan nilai MSA ditentukan oleh; 1) kenaikan ukuran sampel, 2) kenaikan korelasi rata-rata, 3) kenaikan jumlah variabel, atau 4) penurunan jumlah faktor. Santosa (2002) mengemukakan kriteria MSA yang digunakan sebagai berikut.

Tabel 2. Penilaian Uji MSA

\begin{tabular}{ll}
\hline \multicolumn{1}{c}{ Rentang Nilai MSA } & \multicolumn{1}{c}{$\begin{array}{c}\text { Kriteria Kategori } \\
\text { Penilaian }\end{array}$} \\
\hline MSA $=1$ & $\begin{array}{l}\text { variabel dapat diprediksi } \\
\text { tanpa kesalahan oleh } \\
\text { variabel lain }\end{array}$ \\
\hline MSA $\geq 0,5$ & $\begin{array}{l}\text { variabel masih bisa } \\
\text { diprediksi dan dianalisis } \\
\text { lebih lanjut }\end{array}$ \\
\hline MSA $<0,5$ & $\begin{array}{l}\text { variabel dapat dieliminasi } \\
\text { untuk tidak disertakan } \\
\text { dalam analisis faktor }\end{array}$ \\
\hline
\end{tabular}

\section{2) Ekstraksi Faktor}

Ekstraksi faktor adalah proses mereduksi sejumlah variabel menjadi sejumlah set variabel baru atau faktor yang jumlahnya lebih sedikit. Misal terdapat $\mathrm{p}$ variabel asal, setelah diekstraksi akan menjadi $m$ faktor dimana $\mathrm{m}<\mathrm{p}$. Metode ekstraksi faktor berkaitan dengan penentuan jumlah faktor yang menggambarkan struktur data. Supranto (2004) menyatakan bahwa terdapat dua metode yang bisa dipergunakan dalam analisis faktor, khususnya untuk menghitung timbangan atau koefisisen skor faktor, yaitu Principal Component Analysis dan Common Factor Analysis.

Dalam Principal Component Analysis, jumlah varian dalam data dipertimbangkan. Jika tujuan dari penggunaan analisis faktor adalah untuk mereduksi data dan mendapatkan jumlah faktor minimum yang dibutuhkan untuk merepresentasikan data asal, maka direkomendasikan Component Analysis. menggunakan Principal

Di dalam Common Factor Analysis faktor diestimasi berdasarkan common variance, communalities dimasukkan dalam matriks korelasi. Metode ini dianggap tepat kalau tujuan utama penggunaan analisis faktor adalah untuk mengidentifikasi secara teoritis dimensi yang bermakna. Metode ini juga dikenal sebagai principal axis factoring.

Hair, et al. (1998) menyatakan bahwa terdapat beberapa kriteria dalam menentukan sejumlah faktor yang terbentuk, yakni;

\section{a. Kriteria Akar Ciri}

Teknik yang paling sering digunakan adalah dengan melihat akar ciri. Alasan penggunaan akar ciri adalah karena setiap variabel memiliki kontribusi nilai 1 terhadap total akar ciri. Sehingga faktor dengan nilai akar ciri $\geq 1$ yang dianggap signifikan, sedangkan untuk faktor yang nilai akar cirinya $<1$ dianggap tidak signifikan dan harus dikeluarkan dari model.

b. Kriteria Persentase Keragaman

Penentuan jumlah faktor dilihat dari nilai spesifik dari persentase kumulatif keragaman yang bisa dijelaskan oleh faktor yang terbentuk. Dalam penelitian ilmiah ekstraksi faktor tidak akan dihentikan sebelum mencapai total keragaman $95 \%$, namun dalam ilmu sosial batas total keragaman yang digunakan hanya $60 \%$.

c. Kriteria Scree Test

Teknik ini dilakukan dengan membuat plot antara jumlah faktor yang terbentuk (sumbu horizontal) dengan akar ciri (sumbu vertikal). Dengan melihat bentuk dari kurva yang telah diplotkan ditentukan jumlah faktor yang akan digunakan. Semakin melandai kurva maka ekstraksi faktor dihentikan. Setelah menentukan jumlah faktor yang terbentuk, tahap selanjutnya adalah melakukan estimasi nilai loading untuk menetapkan variabel yang menyusun faktor. Johnson, et al (2002) menuliskan dua estimasi nilai loading, yaitu metode komponen utama (principal component analysis) dan metode maximum likelihood. Metode yang paling sering digunakan adalah metode komponen utama. Karena metode maximum likelihood digunakan ketika faktor umum $\mathrm{F}$ dan faktor khusus $\varepsilon$ diasumsikan berdistribusi normal. Metode komponen utama memanfaatkan dekomposisi spektral dari matriks covariance $\Sigma$ untuk mengestimasi nilai loading.

3) Rotasi Faktor

Interpretasi hasil analisis yang dilakukan seringkali menyusahkan. Langkah penting dalam interpretasi faktor adalah rotasi faktor. Menurut Hair, et al (1998) rotasi dilakukan sampai struktur yang lebih sederhana diperoleh. Dua jenis metode untuk rotasi faktor adalah Orthogonal dan Oblique (Rummel, 1970). Rotasi orthogonal mengasumsikan bahwa faktor-faktor terbentuk adalah independent, proses rotasinya dengan mempertimbangkan sudut 900 antar sumbu kedua faktor umum.

Rotasi oblique tidak mengharuskan bahwa sudut yang digunakan adalah 900. Beberapa ahli menyarankan untuk menggunakan rotasi orthogonal yakni varimax (variance of maximum) karena menghasilkan struktur faktor yang sederhana dengan memaksimumkan jumlah varians dari faktor yang memuat nilai loading kuadrat (Johnson, et al., 2002). 
Menurut Wijaya (2010) dengan metode varimax banyak variabel dapat memiliki loading tinggi atau mendekati tinggi pada faktor yang sama karena fokus tekniknya untuk menyederhanakan baris, sehingga kecenderungan memiliki loading tinggi dan beberapa loading mendekati 0 (nol) pada setiap kolom matrik. Oleh karena itu, pada penelitian kali ini metode rotasi yang digunakan adalah rotasi orthogonal dengan varimax.

Rotasi Varimax adalah rotasi yang memaksimalkan faktor pembobot dan mengakibatkan korelasi peubah-peubah dengan suatu faktor mendekati satu serta korelasi dengan faktor lainnya mendekati nol sehingga mudah diinterpretasikan.

Rotasi tersebut menghasilkan matriks loading baru L* yaitu:

$$
\mathrm{L} *(\mathrm{p} \times \mathrm{q})=\mathrm{L}(\mathrm{p} \times \mathrm{q}) . \mathrm{T}(\mathrm{q} \times \mathrm{q})
$$

Dimana $T=$ matriks transformasi yang dipilih sehingga $T^{\prime} T=T T^{\prime}=I$

Matriks tranformasi $\boldsymbol{T}$ ditentukan sedemikian rupa sehingga total keragaman kuadrat loading $\boldsymbol{L}$ menjadi maksimum.

Rotasi merupakan suatu upaya untuk menghasilkan faktor penimbang baru yang lebih mudah diinterpretasikan. Yaitu dengan mengalikan faktor penimbang awal dengan matriks transformasi yang bersifat orthogonal, sehingga matriks korelasinya tidak akan berubah. Dari merotasi matriks loading menyebabkan setiap peubah asal mempunyai korelasi yang tinggi terhadap faktor tertentu saja sedangkan faktor lain mempunyai korelasi relatif sehingga setiap faktor akan lebih mudah diinterpretasikan.

\section{4) Menghitung Skor Faktor}

Skor faktor merupakan ukuran komposit dari masingmasing variabel asal pada masing-masing faktor yang diekstraksi dalam analisis faktor (Hair, et al., 1998). Menurut Supranto (2004), skor faktor merupakan skor komposit yang diestimasi untuk setiap responden pada faktor turunan (derived factors).

Skor faktor biasanya dihitung jika hasil dari analisis faktor akan digunakan untuk analisis lanjutan, karena sebenarnya tanpa menghitung skor faktor hasil dari analisis ini sudah bermanfaat yaitu jika tujuannya hanya ingin mereduksi variabel. Penghitungan skor faktor dalam penelitian ini digunakan untuk mencari nilai penimbang dalam penyusunan indeks komposit.

Dalam penghitungan skor faktor terdapat beberapa metode estimasi yang sering digunakan yaitu metode weight least square dan regresi. Metode weight least square digunakan jika dalam mengestimasi nilai loading digunakan metode maximum likelihood (Johnson, et al., 2002). Oleh karena itu, dalam penelitian ini estimasi nilai loading dilakukan dengan metode komponen utama maka dalam mengestimasi skor faktor digunakan metode regresi.

\section{Analisis Dampak Sosial dan Ekonomi}

Pada analisis dampak yang akan di analisis adalah dampak sosial dan ekonomi yang tujuannya untuk membandingkan sosial dan ekonomi sesudah konversi lahan.

Dampak sosial yang terdapat pada analisis dampak pada Subak Petangan adalah terhambatnya saluran irigasi, tercemarnya air irigasi lahan sawah, kelestarian budaya dan kehidupan sosial masyarakat lokal akan terus terikikis dengan masuknya wisatawan yang secara terus-menerus membawa kebudayaan dan kehidupan sosial yang tidak sesuai dengan kebudayaan lokal, timbulnya kesenjangan sosial antara masyarakat lingkungan sekitar.

Dampak ekonomi yang terdapat pada analisis dampak pada Subak Petangan adalah berkurangnya sumber pangan akibat alih fungsi lahan, petani tidak mempunyai pekerjaan tetap karena semua lahan sawah sudah terjual, meningkatnya tingkat penganguran akibat sudah tidak menjadi petani, adanya perubahan pola kehidupan petani dengan perilaku yang konsumtif dengan menghabiskan uang hasil menjual lahan sawah untuk sesuatu yang tidak menghasilkan dan bermanfaat.

\section{HASIL DAN PEMBAHASAN}

\section{Karakteristik Responden}

Berdasarkan hasil penelitian yang dilakukan pada Subak Petangan, dapat diketahui gambaran tentang karakteristik responden. Uraian tentang karakteristik responden ini melibatkan 40 orang petani pemilik sekaligus penggarap yang sudah habis menjual lahan sawahnya pada Subak Petangan, Kecamatan Denpasar Utara. Adapun identitas responden yang ikut ambil bagian dari penelitian ini meliputi jenis kelamin, umur, dan pendidikan terakhir. Pada aspek jenis kelamin responden penelitian adalah responden laki-laki dengan jumlah 40 orang yang di wawancarai.

\section{Karakteristik responden berdasarkan umur}

Karakteristik responden dalam penelitian ini jika dilihat berdasarkan kelompok umur petani di Subak Petangan, Kecamatan Denpasar Utara. Adapun kelompok umur petani dapat dilihat melalui deskripsi yang termuat pada Tabel 3 .

Berdasarkan hasil penelitian pada Tabel 3 menunjukkan umur responden dominan adalah rentang usia 45-54 tahun yaitu sebanyak 25 orang atau 62,5\%. Melalui data tersebut dapat dilihat bahwa generasi petani yang mengerjakan sawah baik langsung ataupun tidak didominasi oleh rentang umur 45-54 tahun sedangkan berbanding terbalik dengan usia produktif 35-44 tahun yang hanya terdiri dari lima orang. Ini 
menandakan bahwa Subak Petangan ini sudah mengalami krisis generasi oleh karena sedikitnya jumlah usia produktif yang bersedia mengerjakan sawah atau memiliki usaha pertanian sebagai pekerjaan. Kondisi ini tentunya menjadi masalah krusial dimana semakin terbatasnya jumlah usia produktif yang bersedia mengolah lahan pertanian berimplikasi pada semakin ditinggalkannya kegiatan pertanian menjadi kegiatan usaha konsumtif lainnya.

Tabel 3. Distribusi Frekuensi Umur responden

\begin{tabular}{cccc}
\hline No & $\begin{array}{c}\text { Jumlah } \\
\text { Anggota } \\
\text { Keluarga } \\
\text { (Tahun) }\end{array}$ & $\begin{array}{c}\text { Frekuensi } \\
\text { (orang) }\end{array}$ & $\begin{array}{c}\text { Persentase } \\
(\%)\end{array}$ \\
\hline 1 & $35-<45$ & 5 & 12,5 \\
2 & $45-<55$ & 25 & 62,5 \\
3 & $55-<65$ & 10 & 25,0 \\
4 & $>65$ & 0 & 0,0 \\
\hline & Jumlah & 40 & 100 \\
\hline
\end{tabular}

Sumber : Data diolah dari hasil survei

\section{Karakteristik responden berdasarkan pendidikan}

Karakteristik responden dalam penelitian ini jika dilihat berdasarkan tingkat pendidikan petani di Subak Petangan, Kecamatan Denpasar Utara dengan latar belakang pendidikan memiliki pengaruh yang besar terhadap keberlangsungan pengolahan hasil usaha taninya. Dimana pendidikan merupakan suatu wujud sistem pendidikan yang ditempuh dan diperhitungkan sebagai perbaikan kondisi taraf hidup suatu masyarakat di suatu daerah sehingga dengan memperoleh pendidikan dapat mendorong seseorang memiliki pola pikir yang luas dan dapat mengikuti perkembangan teknologi yang akan berdampak positif pada produktivitas, pendapatan dan juga meningkatkan kesejahteraan.

Adapun data tingkat pendidikan petani dapat dilihat melalui deskripsi yang termuat pada Tabel 4.

Tabel 4. Distribusi Frekuensi Tingkat Pendidikan Responden

\begin{tabular}{clcc}
\hline No & $\begin{array}{c}\text { Tingkat } \\
\text { Pendidikan }\end{array}$ & $\begin{array}{c}\text { Frekuensi } \\
\text { (orang) }\end{array}$ & $\begin{array}{c}\text { Persentase } \\
(\%)\end{array}$ \\
\hline 1 & SD & 26 & 65,0 \\
2 & SMP & 7 & 18,0 \\
3 & SMA & 4 & 10,0 \\
4 & DIPLOMA & 2 & 5,0 \\
5 & SARJANA & 1 & 3,0 \\
\hline & Jumlah & 40 & 100 \\
\hline
\end{tabular}

Sumber : Data diolah dari hasil survei
Berdasarkan hasil penelitian pada Tabel 4 dapat diketahui bahwa pendidikan petani di dominasi dengan latar belakang pendidikan Sekolah Dasar (SD) 60 orang atau $65 \%$, latar belakang pendidikan Sekolah Menengah Pertama (SMP) sebesar 7 orang atau $18 \%$, latar belakang pendidikan Sekolah Menengah Atas (SMA) sebesar 4 orang atau $10 \%$, latar belakang pendidikan Diploma sebesar 2 orang atau $5 \%$, dan latar belakang pendidikan Sarjana sebesar 1 orang atau $3 \%$.

Berdasarkan data tersebut tingginya jumlah petani yang berpendidikan Sekolah Dasar (SD) dikarenakan kondisi petani yang hanya mempunyai keterbatasan dalam hal biaya pendidikan yang kurang mampu. Sehingga, dengan kondisi demikian upaya peningkatan pendidikan melalui jalur non formal seperti kursus dan pelatihan sangat diperlukan guna memberikan wawasan serta nantinya memiliki pengaruh positif bagi petani guna mempelajari percepatan alih teknologi yang semakin berkembang pesat.

\section{Hasil Analisis Data}

Teknik Pengumpulan Data melalui kuisioner yang digunakan terdiri atas pernyataan yang dibuat berdasarkan masing-masing variabel, yaitu variabel konversi lahan, faktor internal dan eksternal pendorong konversi lahan. Berikut adalah hasil deskripsi data hasil penelitan konversi lahan pertanian pada Subak Petangan dengan menggunakan analisis faktor (Factor Analysis) dari masing-masing variabel yang diperoleh pada penelitian ini.

\section{Pengujian Indikator Pembentuk Faktor Internal}

Faktor internal pembentuk konversi lahan diukur berdasarkan persepsi responden terhadap indikatorindikator pendorong konversi lahan sesuai dengan definisi operasional variabel. Adapun hasil pengujian indikator pembentuk faktor internal konversi lahan dari jawaban responden dapat dilihat pada Tabel 5.

Pada Tabel 5 indikator- indikator membentuk faktor internal konversi lahan yaitu: (1) jumlah anggota keluarga (X1) yaitu: banyak jumlah anggota keluarga yang dibebankan kepada petani semakin berat petani membiayai anggota keluarganya, (2) tingkat pendidikan (X2) yaitu: pola pikir petani untuk menjual lahan sawahnya, (3) kebutuhan hidup (X3) yaitu: kebutuhan fisiologis, kebutuhan rasa aman, kebutuhan sosial, kebutuhan penghargaan, kebutuhan sosial, kebutuhan penghargaan, kebutuhan aktualisasi diri, dan tingkat pendapatan (X4) yaitu: pendapatan dari hasil pertanian.

Berdasarkan hasil analisis konfirmatory, keempat variabel ini memang benar sebagai pembentuk faktor internal konversi lahan, yang ditunjukkan oleh nilai KMO sebesar 0,671 $(>0,5)$ dan signifikansi kesalahan $5 \% \quad(0,000<)$ (Tabel 3.3 bagian 1). Kebenaran keempat variabel ini diperkuat oleh koefisien korelasi antar variabel pembentuk faktor internal konversi lahan yang semua lebih besar dari 0,5 (Tabel 3.3 bagian 2). Kontribusi dari setiap variabel terhadap 
faktor internal konversi lahan dapat diketahui dari nilai komunalitas. Untuk variabel jumlah anggota keluarga $(\mathrm{X} 1)=53,5 \%$, variabel tingkat pendidikan $(\mathrm{X} 2)=$ $79,7 \%$, variabel tingkat kebutuhan hidup $(\mathrm{X} 3)=$ $79,5 \%$, dan variabel tingkat pendapatan hasil pertanian $(X 4)=90,1 \%$ (tabel 3.3 bagian 3). Ini berarti bahwa nilai komunalitas masing-masing variabel dapat menerangkan variance dari faktor persepsi yang dibentuk, dalam hal ini adalah faktor internal konversi lahan.

Pada Tabel 5 (bagian 4) menunjukkan bahwa faktor internal konversi lahan dapat mewakili komponen pembentuknya sebesar $75,712 \%$ dari total variance, yang berarti bahwa terbentuk satu faktor yang mewakili 4 variabel yaitu X1, X2, X3, dan X4 dengan nilai akar ciri (eigenvalues) diperoleh nilai 3,028 $(>1,00)$. Hasil analisis komponen matrik ditunjukkan tabel 3.3 (bagian 5) yang menunjukkan hubungan atau korelasi dari setiap variabel terhadap faktor yang terbentuk (faktor internal konversi lahan). Semakin tinggi nilai komponen setiap variabel, maka semakin besar pengaruhnya dalam pembentukan faktor internal, demikian juga sebaliknya.

Berdasarkan Tabel 3.3 (bagian 5) dapat diketahui bahwa variabel pembentuk berdasarkan pendapatan hasil pertaniam (X4) mempunyai pengaruh paling besar terhadap faktor inernal konversi lahan dengan koefisien korelasi 0,949. Kemudian diikuti variabel pembentuk berdasarkan tingkat pendidikan (X2) dengan koefisien korelasi 0,893, variabel pembentuk berdasarkan kebutuhan hidup (X3) dengan koefisien korelasi 0,892 , dan yang paling lemah adalah variabel pembentuk berdasarkan jumlah anggota keluarga (X1) dengan koefisien $-0,731$.

Berdasarkan hasil analisis faktor internal pembentuk konversi lahan pada Tabel 5 dapat diinterpretasikan bahwa dari 4 variabel indikator dari jumlah anggota keluarga, tingkat pendidikan, kebutuhan hidup, dan tingkat pendapatan memang benar sebagai pembentuk faktor internal konversi lahan. Namun masing-masing indikator memiliki kontribusi berbeda dalam membentuk persepsi sebagai salah satu pembentuk faktor persepsi.

Pada usaha mencegah konversi lahan, pada jumlah keluarga usaha program pemerintah untuk menekankan angka kelahiran yang cukup tinggi dengan cara program keluarga berencana $(\mathrm{KB})$ yang nantinya akan membantu beban kepala keluarga dalam membiayai anggota keluarganya. Pada pendidikan petani harus menyadari bahwa pendidikan sangat penting dalam mendapatkan ilmu untuk meningkatkan potensi diri dalam hal pertanian maka petani harus mengikuti seminar atau mengikuti kursus mengenai pertanian yang biasanya diselenggarakan oleh pemerintah atau masyarakat yang menyelenggarakan yang nantinya dapat membantu dalam hal mendapatkan informasi mengenai pertanian. Pada kebutuhan hidup tentang Teori Maslow, pada kebutuhan dasar (pokok) petani harus memenuhi terlebih dahulu sebelum menginginkan kebtuhan yang lain agar nantinya tidak tumpang tindih antara kebutuhan dasar (pokok) dengan kebutuhan tidak pokok. Pada tingkat pendapatan dari hasil pertanian petani dapat mencari tambahan penghasilan dari sektor non pertanian seperti bekerja pada sektor jasa atau membuka usaha yang nantinya dapat sebagai biaya tambahan untuk menghidupi kebutuhan keluarganya. Hal tersebut bertujuan untuk mempertahankan ketahanan pangan yaitu beras sebagai ketahanan pangan nasional yang nantinya dapat memenuhi kuota beras pada masing-masing daerah sehingga tidak terjadi krisris pangan dan harga yang akan melonjak.

Tabel 5. Nilai-Nilai Stastistik Faktor-Faktor Internal Pembentuk Motivasi Konversi Lahan di Subak Petangan Kecamatan Denpasar Utara

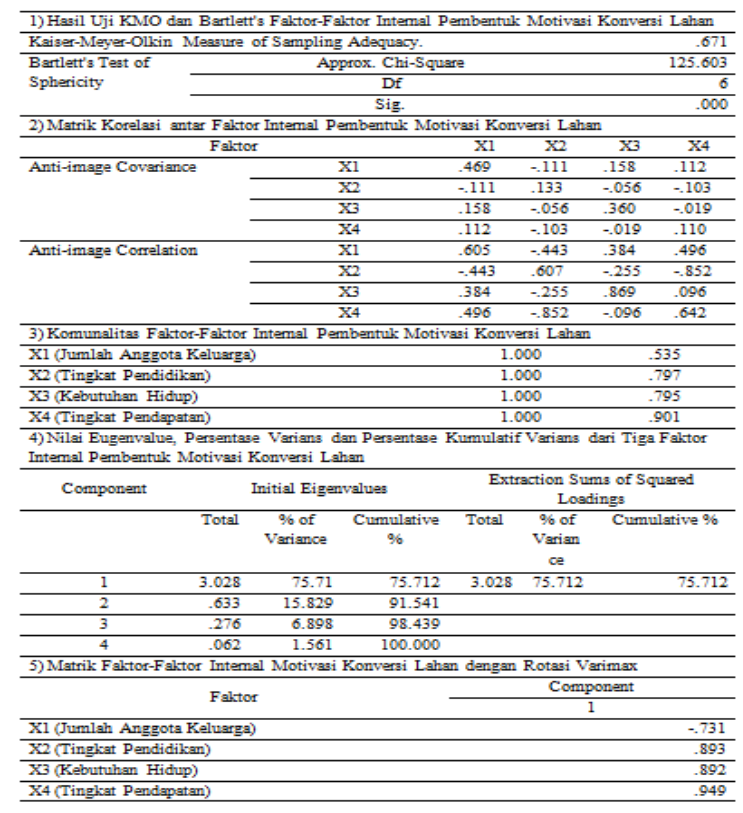

Pengujian Indikator Pembentuk Faktor Eksternal

Faktor eksternal pembentuk konversi lahan diukur berdasarkan persepsi responden terhadap indikatorindikator pendorong konversi lahan sesuai dengan definisi operasional variabel. Adapun hasil pengujian indikator pembentuk faktor eksternal konversi lahan dari jawaban responden dapat dilihat pada Tabel 5.4.

Pada Tabel 6 indikator- indikator membentuk faktor eksternal konversi lahan yaitu: (1) gaya hidup (X5) yaitu: kebutuhan akan gaya hidup masyarakat yang konsumtif, (2) minat generasi muda untuk bertani (X6) yaitu: generasi pertanian yang berkelanjutan pada masa depannya, (3) akses pengelolaan Lahan (X7) yaitu: mudahnya akses menuju ke lahan sawah, (4) ketersediaan air irigasi (X8) yaitu: cukupnya air irigasi dalam pertanian.

Berdasarkan hasil analisis konfirmatory, keempat variabel ini memang benar sebagai pembentuk faktor eksternal konversi lahan, yang ditunjukkan oleh nilai 
KMO sebesar 0,688 (>0,5), dan signifikansi kesalahan $5 \%(0,000<)$ (Tabel 6 bagian 1$)$. Kebenaran keempat variabel ini diperkuat oleh koefisien korelasi antar variabel pembentuk faktor eksternal konversi lahan yang semua lebih besar dari 0,5 (Tabel 3.4 bagian 2). Kontribusi dari setiap variabel terhadap faktor eksternal konversi lahan dapat diketahui dari nilai komunalitas. Untuk variabel jumlah anggota keluarga $(\mathrm{X} 5)=67,6 \%$, variabel tingkat pendidikan $(\mathrm{X} 6)=$ $71,8 \%$, variabel tingkat kebutuhan hidup $(\mathrm{X} 7)=$ $62,7 \%$, dan variabel tingkat pendapatan hasil pertanian $(X 8)=68,6 \%$ (tabel 6 bagian 3). Ini berarti bahwa nilai komunalitas masing-masing variabel dapat menerangkan variance dari faktor persepsi yang dibentuk, dalam hal ini adalah faktor eksternal konversi lahan. Pada Tabel 6 (bagian 4) menunjukkan bahwa faktor eksternal konversi lahan dapat mewakili komponen pembentuknya sebesar $67,665 \%$ dari total variance, yang berarti bahwa terbentuk satu faktor yang mewakili 4 variabel yaitu X5, X6, X7, dan X8 dengan nilai akar ciri (eigenvalues) diperoleh nilai 2,707 (>1,00). Hasil analisis komponen matrik ditunjukkan Tabel 3.4 (bagian 5) yang menunjukkan hubungan atau korelasi dari setiap variabel terhadap faktor yang terbentuk (faktor eksternal konveri lahan). Semakin tinggi nilai komponen setiap variabel, maka semakin besar pengaruhnya dalam pembentukan faktor eksternal, demikian juga sebaliknya.

Berdasarkan Tabel 6 (bagian 5) dapat diketahui bahwa variabel pembentuk berdasarkan ketersediaan air irigasi (X8) mempunyai pengaruh paling besar terhadap faktor eksternal konversi lahan dengan koefisien korelasi 0,828 . Kemudian diikuti variabel pembentuk berdasarkan gaya hidup (X5) dengan koefisien korelasi 0,822 , variabel pembentuk tingkat akses pengelolaan lahan (X7) dengan koefisien korelasi 0,792 , dan yang paling lemah adalah variabel pembentuk berdasarkan minat generasi muda untuk bertani (X6) dengan koefisien $-0,848$.

Berdasarkan hasil analisis faktor eksternal pembentuk konversi lahan pada Tabel 6 dapat diintepretasikan bahwa dari 4 variabel indikator dari gaya hidup, minat generasi muda untuk bertani, akses pengelolaan lahan, dan tingkat ketersediaan air irigasi memang benar sebagai pembentuk faktor eksternal konversi lahan. Namun masing-masing indikator memiliki kontribusi berbeda dalam membentuk persepsi sebagai salah satu pembentuk faktor persepsi.

Pada usaha mencegah konversi lahan pada gaya hidup petani harus tetap hidup yang tidak berlebihan walaupun terkena imbas dari gaya hidup di zaman perkotaan sekarang ini agar nantinya tidak menghamburkan kemewahan yang dapat membuat petani menghabiskan uangnya dalam hal konsumtif. Pada minat generasi muda untuk bertani bahwa pemerintah bisa memberikan beasiswa kepada generasi muda untuk bersekolah pada bidang pertanian sehingga membuat daya tarik dari generasi muda berminat untuk berkecimpung pada sektor pertanian. Pada akses pengelolaan lahan pemerintah bisa membuat sarana yang dapat membantu petani dalam bertani seperti membuat jalan usaha tani (JUT) yang nantinya petani tidak bersusah payah ke tempat lahan sawahnya dalam melakukan kegiatan bertani sehingga sangat membantu petani nantinya dalam bercocok tanam. Pada ketersediaan air irigasi pemerintah dengan kesadaran anggota Subak yang anggotanya adalah petani dalam hal bergotong royong memperbaiki saluran irigasi agar air irigasi dapat tersalurkan merata ke lahan-pahan sawah petani, membagi air yang di dapatkan di bagikan dengan merata kepada seluruh anggota petani Subak agar walau air yang didapatkan sedikit asal berkecukupan. Namun Pekaseh Subak dapat membuat peraturan mengenai pencemaran air irigasi yang disebabkan oleh sampah rumah tangga agar nantinya tidak menimbulkan konflik yang berkepanjangan antara petani dan pemilik rumah di pemukiman.

Tabel 6. Nilai-Nilai Stastistik Faktor-Faktor Eksternal Pembentuk Motivasi Konversi Lahan di Subak Petangan Kecamatan Denpasar Utara

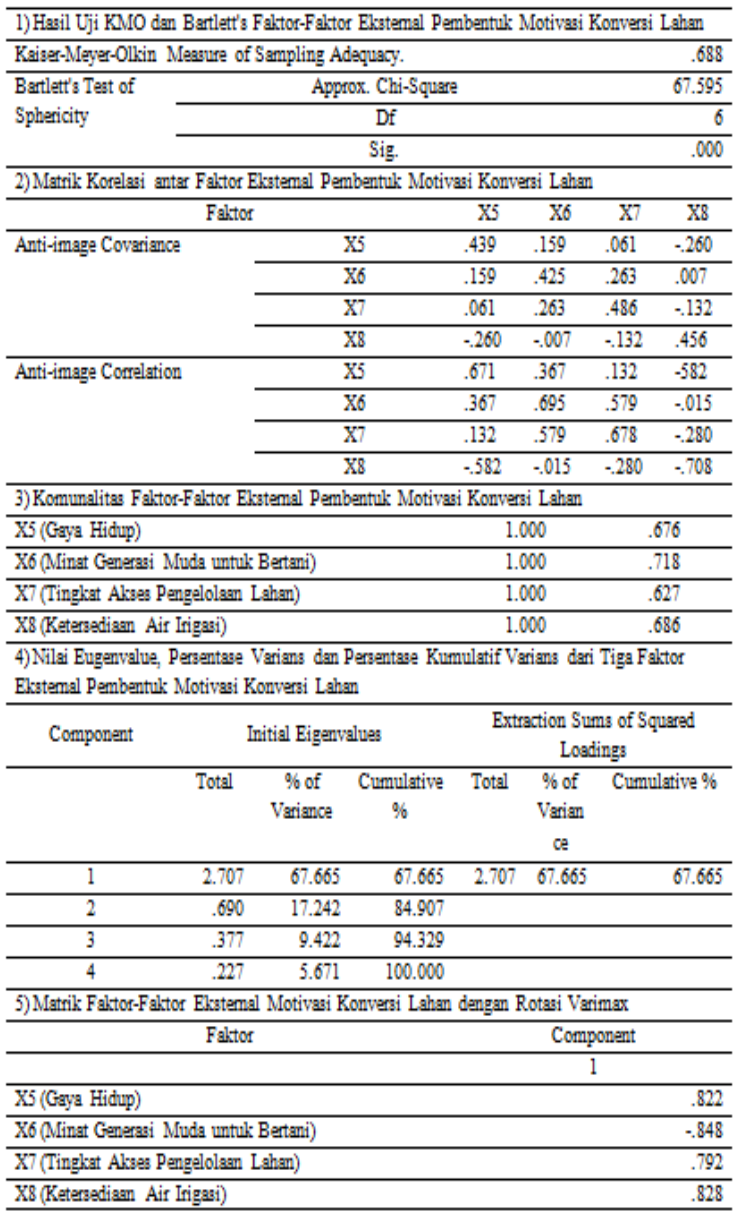

I Gusti Jaya, et al., Konversi...|26 


\section{Faktor-Faktor Yang Mempengaruhi Konversi Lahan Di Subak Petangan}

Faktor faktor yang mempengaruhi konversi lahan diukur berdasarkan persepsi responden terhadap indikator-indikator pendorong konversi lahan sesuai dengan definisi operasional variabel. Adapun hasil pengujian indikator pembentuk rata-rata gabungan faktor internal dan eksternal konversi lahan dari jawaban responden dapat dilihat pada Tabel 7.

Pada Tabel 7 indikator- indikator membentuk gabungan rata-rata faktor internal (F1) dan faktor eksternal (F2) konversi lahan yaitu: pada faktor internal (F1) antara lain: (1) jumlah anggota keluarga (X1) yaitu: banyak jumlah anggota keluarga yang dibebankan kepada petani semakin berat petani membiayai anggota keluarganya, (2) tingkat pendidikan (X2) yaitu: pola pikir petani untuk menjual lahan sawahnya, (3) kebutuhan hidup (X3) yaitu: kebutuhan fisiologis, kebutuhan rasa aman, kebutuhan sosial, kebutuhan penghargaan, kebutuhan sosial, kebutuhan penghargaan, kebutuhan aktualisasi diri, dan tingkat pendapatan (X4) yaitu: pendapatan dari hasil pertanian. Pada faktor eksternal (F2) antara lain: (1) gaya hidup (X5) yaitu: kebutuhan akan gaya hidup masyarakat yang konsumtif, (2) minat generasi muda untuk bertani (X6) yaitu: generasi pertanian yang berkelanjutan pada masa depannya, (3) akses pengelolaan Lahan (X7) yaitu: mudahnya akses menuju ke lahan sawah, (4) ketersediaan air irigasi (X8) yaitu: cukupnya air irigasi dalam pertanian.

Berdasarkan hasil analisis konfirmatory, keempat variabel ini memang benar sebagai pembentuk ratarata faktor internal dan eksternal konversi lahan, yang ditunjukkan oleh nilai KMO sebesar 0,500 $(>0,5)$, dan signifikansi kesalahan 5\% $(0,000<$ ) (Tabel 7 bagian 1). Kebenaran keempat vaiabel ini diperkuat oleh koefisien korelasi antar variabel pembentuk faktor internal konversi lahan yang semua lebih besar dari 0,5 (Tabel 7 bagian 2). Kontribusi dari setiap rata-rata variabel terhadap faktor internal dan ektsternal konversi lahan dapat diketahui dari nilai komunalitas. Untuk variabel rata-rata faktor internal $(\mathrm{F} 1)=92,1 \%$ dan rata-rata faktor eksternal $(\mathrm{F} 2)=92,1 \%$ (Tabel 7 bagian 3). Ini berarti bahwa nilai komunalitas masingmasing variabel dapat menerangkan variance dari faktor persepsi yang dibentuk, sama pada kedua faktor konversi lahan. Pada Tabel 7 (bagian 4) menunjukkan bahwa nilai total variance sebesar $92,149 \%$, yang berarti bahwa terbentuk satu faktor yang mewakili 2 variabel yaitu $\mathrm{F} 1$ dan $\mathrm{F} 2$ dengan nilai akar ciri (eigenvalues) diperoleh nilai $1,843(>1,00)$. Hasil analisis komponen matrik ditunjukkan Tabel 7 (bagian 5) yang menunjukkan hubungan atau korelasi dari setiap variabel terhadap faktor yang terbentuk (faktor eksternal konversi lahan). Pada rata-rata gabungan ini menunjukkan nilai komponen yang sama, sehingga kedua faktor tersebut memiliki pengaruh yang sama didalam pembentukan faktor-faktor konversi lahan.

Berdasarkan Tabel 7 (bagian 5) dapat diketahui bahwa rata-rata variabel faktor internal dan eksternal pembentuk berdasarkan persepsi alih fungsi lahan memiliki nilai koefisien sama yaitu koefisien 0,960 . Sehingga dapat diketahui bahwa variabel pembentuk berdasarkan persepsi responden memiliki keterkaitan yang erat dan berperan dalam membentuk faktor persepsi terhadap konversi lahan sawah di Subak Petangan. Hal ini tentunya berdasarkan faktor internal dan faktor eksternal yang diperoleh dari kuesioner yang disebarkan.

Berdasarkan hasil analisis faktor gabungan rata-rata pembentuk konversi lahan pada Tabel 7 dapat diintepretasikan bahwa rata-rata dari 8 variabel indikator internal terdiri dari jumlah anggota keluarga, pendidikan, kebutuhan hidup, tingkat pendapatan hasil pertanian. Indikator eksternal yaitu gaya hidup, minat generasi muda untuk bertani, akses pengelolaan lahan, dan tingkat ketersediaan air irigasi memang benar sebagai pembentuk faktor internal dan eksternal konversi lahan. Namun masing-masing indikator memiliki kontribusi berbeda dalam membentuk persepsi sebagai salah satu pembentuk faktor persepsi maka faktor internal dan eksternal ini bertujuan untuk mengerem laju konversi lahan. I

Tabel 7. Nilai-Nilai Stastistik Rata-Rata Gabungan Faktor Internal dan Eksternal Pembentuk Motivasi Konversi Lahan di Subak Petangan Kecamatan Denpasar Utara

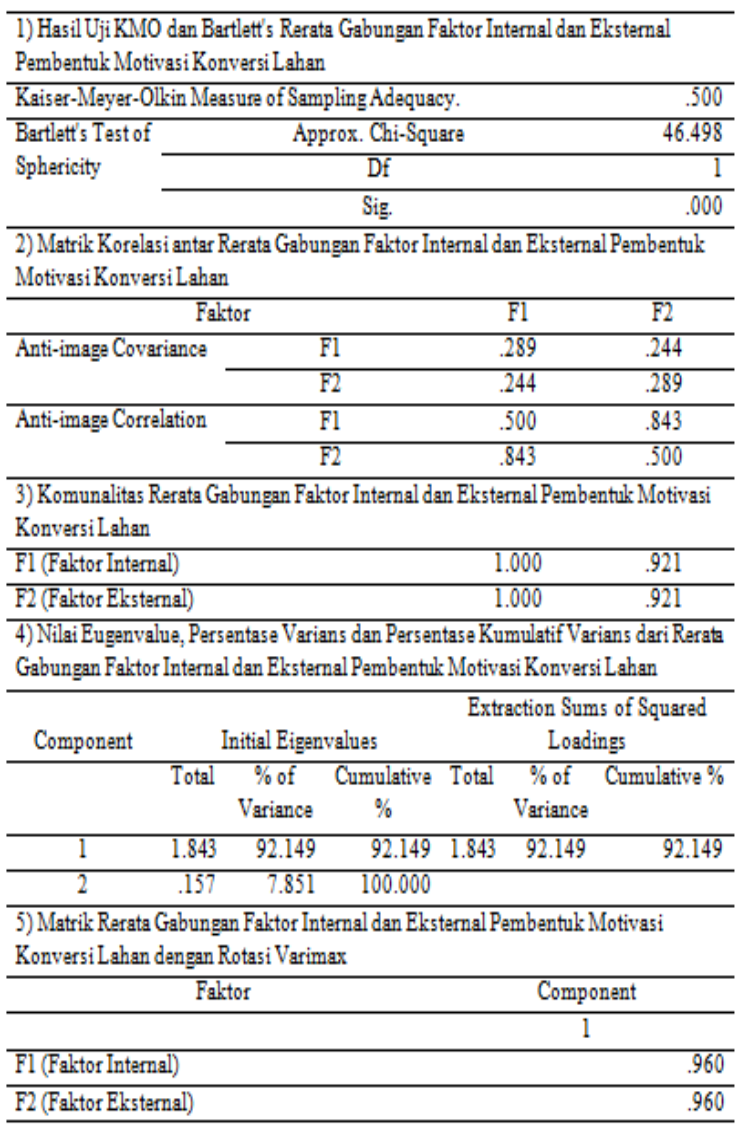




\section{Dampak Konversi Lahan Terhadap Kondisi Sosial dan Ekonomi Petani di Subak Petangan Kecamatan Denpasar Utara}

\section{Dampak Sosial}

Dampak alih fungsi lahan dari segi sosial juga sangat dirasakan sangat beragam oleh petani di Subak Petangan yang lahannya mengalami konversi. Berikut dampak sosial dalam konversi lahan sawah di Subak Petangan Kecamatan Denpasar Utara sebagai berikut.

1) Terhambatnya saluran air irigasi

Terhambatnya saluran air irigasi tersebut adanya bangunan atau pemukiman yang ada di tengah lahan sawah pertanian karena saluran air irigasi terutup oleh bangunan-bangunan yang ada di sekitar lahan sawah.

2) Tercemarnya air irigasi lahan sawah

Tercemarnya air irigasi diakibatkan sampah plastik dan limbah rumah tangga yang disebabkan oleh pemukiman di sekitar lahan sawah pertanian di areal Subak Petangan.

3) Timbulnya konflik antara petani dengan pemilik pemukiman

Timbulnya konflik anatar petani dengan pemilik pemukiman disebabkan karena air irigasi yang tersendat akibat kesadaran masyarakat di pemukiman yang dibuang dan membuat saluran air irigasi tersendat dan pencemaran air irigasi yang dapat menimbulkan kerusakan lingkungan pada lahan sawah.

4) Terkikisnya nilai budaya Subak

Terkikisnya nilai budaya masyarakat tani dalam wadah subak yang melekat aktivitas ritual upacara agama hindu yang ada di tingkat Subak. Maraknya konversi lahan di Subak Petangan dan sedikitnya anggota Subak membuat upacara ritual yang biasa dilakukan pada Subak Petangan yang biasanya ritual upacara dilakukan 2 kali dalam setahun menjadi setahun sekali. Nilai-nilai Tri Hita Karana yang menjadi basis budaya subak, mulai berkurang karena adanya pengaruh kepeningan ekonomi yang mengakibatkan aktivitas gotong-royong semakin sedikit.

\section{Dampak Ekonomi}

Dampak alih fungsi lahan dari segi ekonomi dirasakan sangat beragam oleh petani di Subak Petangan yang lahannya mengalami konversi. Berikut dampak ekonomi dalam konversi lahan sawah di Subak Petangan Kecamatan Denpasar Utara sebagai berikut.

1) Bekurangnya sumber pangan

Petani yang menjual lahan sawahnya yang merasa bahwa alih fungsi lahan justru mengakibatkan penurunan sumber pangan dapat mengakibatkan harga pangan yang akan semakin meningkat karena lahan yang terbatas untuk melukan produksi suatu komoditi pangan.

2) Petani tidak mempunyai pekerjaan tetap Petani setelah menjual lahan sawahnya sebagian ada yang tidak bekerja hanya dapat menghabiskan uangnya untuk kegiatan upacara adat serta konsumtif. Ini akan mengakibatkan uang nya akan habis karena tidak mempunyai penghasilan yang tetap.

3) Meningkatnya tingkat pengangguran

Meningkatnya tingkat pengangguran disebabkan oleh petani yang sudah menjual semua lahan sawahnya tetapi tidak bekerja hanya bisa menghabiskan sisa hasil lahan sawahnya serta berdampak juga kepada petani penggarap bukan pemilik yang dulu pernah bekerja di sawah pertanian tidak dapat bekerja karena lahan sawah sudah habis terjual semua.

4) Adanya perubahan pola kehidupan petani Pada Perubahan pola kehidupan petani, petani yang menjual lahan sawahnya akan mengikuti perubahan kehidupan yang menjadi modern mengikuti zaman dengan perilaku yang konsumtif dengan membeli yang tidak pokok untuk kehidupannya sehingga ini yang membuat sebagian petani yang semua menjual lahan sawahnya tidak dapat membuat kehidupannya menjadi lebih baik karena tidak bisa mengatur keuangan dengan baik, petani akan menjadi jatuh miskin.

\section{SIMPULAN DAN SARAN}

\section{Simpulan}

Berdasarkan hasil dan pembahasan yang telah dilakukan dalam penelitian mengenai konversi lahan di Subak Petangan, Kecamatan Denpasar Utara, maka dapat disimpulkan sebagai berikut. konversi lahan dipengaruhi oleh faktor internal dan eksternal. Faktor internal dibentuk oleh jumlah anggota keluarga, pendidikan, kebutuhan hidup, pendapatan hasil pertanian. Faktor eksternal dibentuk oleh indikator gaya hidup, minat generasi muda untuk bertani, akses pengelolaan lahan, ketersediaan air irigasi; dan dampak konversi lahan terhadap sosial yaitu terhambatnya saluran air irigasi, tercemarnya air irigasi lahan sawah, timbulnya konflik antara petani dengan pemilik pemukiman, terkikisnya nilai budaya di Subak Petangan Kecamatan Denpasar Utara. Pada dampak ekonomi yaitu bekurangnya sumber pangan, petani tidak mempunyai pekerjaan tetap, meningkatnya tingkat pengangguran, adanya perubahan pola kehidupan petani.

\section{Saran}

Berdasarkan kesimpulan diatas maka dapat disarankan sebagai berikut. seluruh pihak terkait baik pemerintah maupun prajuru subak harus mampu untuk mengontrol dan membuat program atau aturan dalam menekan laju konversi lahan dengan pengelolaan indikator-indikator faktor internal dan eksternal tujuannya agar lahan pertanian tidak semakin terkikis oleh zaman untuk mempertahankan ketahanan pangan nasional dan dampak sosial dan ekonomi dalam konversi lahan di Subak Petangan sangat berdampak buruk terhadap lingkungan dan budaya pada lahan 
sawah Subak Petangan. Pada hal ini Pekaseh Subak dan pemerintah bisa membantu dan saling bekerja sama dalam menjaga Subak agar tidak semakin meningkat alih fungsi lahan sawah.

\section{Ucapan Terimakasih}

Penulis mengucapkan terimakasih kepada seluruh petani di Subak Petangan Kecamatan Denpasar Utara, seluruh dosen di fakultas pertanian Universitas Udayana, seluruh pegawai di lingkungan Dinas Pertanian Kota Denpasar, dan pihak-pihak lainnya yang senantiasa membantu dalam penyusunan E-jurnal ini.

\section{DAFTAR PUSTAKA}

Hair, J.F., at al. 1998. Multivariate Data Analysis, 5th Edition, New Jersey: Prentice- Hall, Inc. [Makalah Online]. http://mmt.its.ac.id/download/SEMNAS/SE MNAS\%20I/Prosiding\%20Buana\%20Ma'ruf .pdf. Diunduh pada tanggal 6 November 2017.

Johnson, R.A., dan Wichern, D.W. 2002. Applied Multivariate Statistical Analysis Fifth Edition.Upper Saddle River, New Jersey: Prentice Hall.

Rummel, R.J. 1970. Applied Factor Analysis. Evanston. IL : Northwestern Uiversity Press.

Suryanto. 1988. Metode Statistika Multivaria. Jakarta: Direktorat Jenderal Pendidikan Tinggi. Departemen Pendidikan dan Kebudayaan.

Santoso, S. 2002 Statistik Parametrik, Cetakan Ketiga, PT Gramedia Pustaka Utama, Jakarta.

Supranto, J. 2004. Analisis Multivariat Arti dan Interpretasi. Jakarta: Rieke Cipta 